\title{
Hypertension in malignancy-an underappreciated problem
}

\author{
Jolanta Małyszko ${ }^{1,2}$, Maciej Małyszko ${ }^{1}$, Leszek Kozlowski ${ }^{3}$, Klaudia Kozlowska ${ }^{1}$ \\ and Jacek Małyszko ${ }^{4}$ \\ 12nd Department of Nephrology and Hypertension with Dialysis Unit, Medical University in Bialystok, Bialystok, Poland \\ ${ }^{2}$ Department of Nephrology, Dialysis and Internal Medicine, Warsaw Medical University, Warsaw, Poland \\ ${ }^{3}$ Department of Oncological Surgery, Regional Cancer Center, Bialystok, Poland \\ ${ }^{4}$ 1st Department of Nephrology and Transplantology with Dialysis Unit, Medical University in Bialystok, Bialystok, Poland \\ Correspondence to: Jolanta Małyszko, email: jolmal@poczta.onet.pl
} Keywords: malignancy; hypertension

Received: October 09, $2017 \quad$ Accepted: March 19, $2018 \quad$ Published: April 17, 2018

Copyright: Małyszko et al. This is an open-access article distributed under the terms of the Creative Commons Attribution License 3.0 (CC BY 3.0), which permits unrestricted use, distribution, and reproduction in any medium, provided the original author and source are credited.

\section{ABSTRACT}

Hypertension is one of the most common comorbidities in cancer patients with malignancy, in particular, in the elderly. On the other hand, hypertension is a longterm consequence of antineoplastic treatment, including both chemotherapy and targeted agents. Several chemotherapeutics and targeted drugs may be responsible for development or worsening of the hypertension. The most common side effect of anti-VEGF (vascular endothelial growth factor) treatment is hypertension. However, pathogenesis of hypertension in patients receiving this therapy appears to be associated with multiple pathways and is not yet fully understood. Development of hypertension was associated with improved antitumor efficacy in patients treated with anti-antiangiogenic drugs in some but not in all studies. Drugs used commonly as adjuvants such as steroids, erythropoietin stimulating agents etc, may also cause rise in blood pressure or exacerbate preexisiting hypertension. Hypotensive therapy is crucial to manage hypertension during certain antineoplastic treatment. The choice and dose of antihypertensive drugs depend upon the presence of organ dysfunction, comorbidities, and/or adverse effects. In addition, severity of the hypertension and the urgency of blood pressure control should also be taken into consideration. As there are no specific guidelines on the hypertension treatment in cancer patients we should follow the available guidelines to obtain the best possible outcomes and pay the attention to the individualization of the therapy according to the actual situation.

\section{INTRODUCTION}

With the recent success of modern cancer therapy, cancer can be curable, and in cases where cure cannot be achieved, it can be treated as a chronic disease. As a result, there are now more than 13 million cancer survivors in the US alone [1] and close to 30 million worldwide [2]. Given the growing population of patients once treated (or continuing treatment) for cancer, the medical community must learn how to best minimize the complications of cancer treatment.
The effects of anticancer treatment on cardiovascular system are of utmost importance to the overall well-being of cancer survivors [3] as a growing number of subjects with higher prevalence of hypertension, valvular disease, cardiomyopathy and heart failure, and pulmonary disease compared with the general population [4]. Due to the fact that, these comorbidities are associated with higher morbidity and mortality, the most important priority is the recognition of the necessity of improvement prevention, diagnosis, and therapy of cardiovascular and pulmonary disorders. 


\section{HYPERTENSION AS A COMORBIDITY}

Hypertension is a long-term consequence of many cancer therapies, including both chemotherapy and targeted agents. Arterial hypertension appears to be the most common entity in cancer patients and its incidence is rising in line with growing population of the elderly in the developed world [5]. It has been reported that prevalence of hypertension in patients with malignancy was around $30 \%$ [6]. It has been also the most common comorbidity reported in cancer registries [7]. However, the detailed data are lacking.

\section{HYPERTENSION AS A COMPLICATION OF THE THERAPY}

Some cancers such as renal cell carcinoma may cause secondary hypertension. What is even more important that some active treatments i.e. inhibitors of vascular endothelial growth factor-VEGF receptor may lead to or worse previously well controlled hypertension [8-12]. It has been reported that incidence of overall hypertension was $20-44 \%$ and the high-grade hypertension was $6-17 \%$, in particular during active therapy [8-12]. Prevalence of hypertension depends upon age, prior hypertension or cardiovascular disease in anamnesis, type of malignancy (renal or non-renal), type of therapy and dose, chemotherapy regimen and concomitant medications. However, the long-term effects on blood pressure are unknown. Table 1 present antineoplastic agents, type of nephrotoxicity, mechanisms, renal adverse effects preventive measures and proposed hypotensive drugs.

\section{Cisplatin derivatives}

Among chemotherapeutic agents, the most data have been reported for cisplatin and come from basic science data and from the evaluation of men treated for testicular cancer $[13,14]$. Unfortunately, few data exist for women who received a platinum agents. Cisplatin exerts cytotoxic effects via the formation of covalent adducts with DNA purine bases and inter and intra-strand cross-links, which can persist in multiple organ systems and circulate for many years after exposure [15-17]. At the vascular level, cisplatin appears to abolish capillary beds [18]. Furthermore, animals treated with cisplatin demonstrate increased levels of tumor necrosis factor (TNF) alpha and multiple cytokines [19] and markers of oxidative stress [20]. Although speculative, these factors may help to explain long-standing toxicities related to cisplatin, including hypertension. In survivors of testicular cancer observed for 11.2 years (median), has a higher blood pressure level together with a risk of incident hypertension, which was significantly elevated relative to healthy controls (odds ratio [OR] 1.4, 95\% CI 1.2
1.7). [13]. Subgroup analyses demonstrated that the age adjusted odds of hypertension was greatest in the group given cisplatin, particularly at dosages $>850 \mathrm{mg}$ (OR 2.4, $95 \%$ CI 1.4-4.0). Another study showed that testicular cancer survivors, who had received chemotherapy and were observed for 19 years (median), had an increased prevalence of antihypertensive medication use compared with the general population (OR 3.7, 95\% CI 1.9-5.2) [14].

\section{Proteasome inhibitors}

Chari and Hajje [21] reported the retrospective data on 67 myeloma patients with patients with relapsed and/or refractory disease treated at Mount Sinai Medical Center, USA. They described 12 patients who suffered from either or cardiac or vascular-related side effects associated with carfilzomib-based treatment (median age was 59 years, with ranges from 49 to 77 years). In one case the hypertension and lack of other signs of renal impairment suggested that the side effect was of vascular origin. In another subject, acute exacerbation of chronic hypertension during carfilzomib treatment was probably due to renal fibromuscular dysplasia. The authors recommended to carefully evaluate the blood pressure and hypotensive treatment, in order to diminish the risk of kidney impairment. In patients with chronic kidney disease, it is of utmost importance to establish if whether the worsening of kidney function is due to the therapy or to progression of the diseases to introduce the appropriate management of this condition.

\section{Anthracyclines}

It has been known that anthracyclines are responsible for congestive heart failure, especially when given in high cumulative doses [22]. However, in 1979 von Hoff et al. [23] retrospectively analyzed 4018 patients from the cooperative group trials and described for the first time the association between doxorubin toxicity and hypertension. Hypertension was a predisposing factor for development of congestive heart failure. Similar data were published by Hequet et al. [24] who found that preexisting hypertension was a risk factor for late subclinical cardiomyopathy in subjects with lymphoma treated with anthracyclines as well as in breast cancer patients [25]. In 9,438 subjects with DLBCL- diffuse large B-cell lymphoma, 3,164 (42\%) received doxorubicinbased chemotherapy, $73 \%$ of them had hypertension, hypertension was synergistic with doxorubicin to cause development of chronic heart failure [26]. The possible mechanism is multifactorial and include oxidative stress with apoptotic/fibrotic inflammatory changes in vascular wall together with endothelial dysfunction [25-28]. Heart failure is the major complication after anthracyclines given with or without trastuzumab. As shown by Russo 
Table 1: Anticancer drugs, type of nephrotoxicity, mechanism and prevention of renal adverse events

\begin{tabular}{|c|c|c|c|c|}
\hline Medication & Cardiotoxicity & Mechanism of action & $\begin{array}{l}\text { Likelihood of } \\
\text { HT }\end{array}$ & $\begin{array}{c}\text { Proposed hypotensive } \\
\text { therapy }\end{array}$ \\
\hline $\begin{array}{l}\text { Alkylating agents } \\
\text { cyclophosphamide }\end{array}$ & HT & $\begin{array}{l}\text { endothelial dysfunction, } \\
\text { arterial vasoconstriction, renal } \\
\text { and vascular damage }\end{array}$ & + & $\begin{array}{l}\text { RAAS blockade } \\
\text { (ACEi, ARB) }\end{array}$ \\
\hline $\begin{array}{l}\text { Antimetabolites } \\
\text { methotrexate } \\
\text { gemcitabine }\end{array}$ & HF, HT, & $\begin{array}{l}\text { Drug-induced- thrombotic } \\
\text { microangiopathy-DITMA }\end{array}$ & + & \\
\hline mTOR & HT & Podocyte damage, & + & RAAS (ACEi, ARB) \\
\hline Platinum derivatives & HT & $\begin{array}{c}\text { Oxidative stress, renal } \\
\text { damage }\end{array}$ & + & \\
\hline $\begin{array}{l}\text { Anti-angiogenesis drugs } \\
\text { VEGF pathway inhibitors- } \\
\text { Bevacizumab, } \\
\text { Aflibercept } \\
\text { Sorafenib } \\
\text { Sunitinib } \\
\text { Pazopanib } \\
\text { Vandetanib } \\
\text { Axitinib } \\
\text { Regorafenib } \\
\text { cabozantinib }\end{array}$ & $\begin{array}{l}\text { hypertension } \\
\text { thrombotic } \\
\text { microangiopathy }\end{array}$ & $\begin{array}{l}\text { Peripheral vascular resistance, } \\
\text { reduced formation of nitric } \\
\text { oxide in endothelium, } \\
\text { increased synthesis of } \\
\text { vasoconstrictive factors, } \\
\text { kidney damage }\end{array}$ & +++ & $\begin{array}{c}\text { RAAS (ACEi, ARB) } \\
\text { CCB }\end{array}$ \\
\hline HER2 inhibitors & LVD, HF/HT & $\begin{array}{l}\text { Oxidative stress, apoptotic/ } \\
\text { fibrotic changes in vascular } \\
\text { wall, endothelial dysfunction }\end{array}$ & + & $\begin{array}{l}\text { RAAS (ACEi, ARB), } \\
\text { beta-blockers }\end{array}$ \\
\hline
\end{tabular}

Anticancer drugs, type of nephrotoxicity, mechanism and prevention of renal adverse events.

HT-hypertension, HF- heart failure, LVD- left ventricular dysfunction, mTOR- mammalian target of rapamycin, VEGF- vascular endothelial growth factor, RAAS-renin-angiotensin-aldosteron system, ACEi - angiotensin converting enzyme inhibitor, ARBangiotensin receptor blocker, CCB- calcium channel blockers.

et al. [29] new onset chronic heart failure with a significant reduction in left ventricular ejection fraction was predicted by a history of hypertension. In addition, cardiotoxicity caused by breast cancer therapy was increased in smokers, patients with obesity, dyslipidemia, diabetes, hypertension or prior history of cardiovascular disorders. Moreover, randomized controlled trials did report consistently decreased cardiotoxicity than found in observational studies [30]. Therefore, diagnosis of hypertension (using new American Heart Association-AHA guidelines from 2017) [31] and timely and appropriate treatment may diminish the incidence of heart failure related to cancer therapy.

\section{Gemcitabine}

Gemcitabine, is a pyrimidine antagonist, that was linked with thrombotic microangiopathy-TMA [32] Recently, it has been reported that 29 patients gemcitabineassociated TMA also developed acute kidney injuryAKI. Hypertension, either de novo or worsening of the preexisting was found in 26 subjects, while congestive heart failure was observed in 7 cases. Withdrawal of the offending causative drug is the primary approach for TMA associated with chemotherapy. Improved clinical performance is seen after withdrawal in some, but not all instances [33, 34]. 


\section{Mammalian target of rapamycin-mTOR inhibitors}

Inhibitors of mTOR such as everolimus, temsirolimus, and ridaforolimus have shown anticancer activity in various malignances, most notably advanced renal cell carcinoma-RCC [35-37]. However, some their immunosuppressive and anticancer properties are linked with several side effects such as diabetes, hyperlipidemia, proteinuria, or hypertension) [38-40] and others [41].

\section{Other drugs}

Alkylating agent cyclophosphamide has been reported to be associated with cardiotoxicity hypertension probably by causing endothelial dysfunction, arterial vasoconstriction together with renal and vascular damage $[42,43]$.

Glucocorticosteroids, mainly dexamethasone, are used commonly as adjuvants and may cause hypertension due to salt and volume retention [44, 45]. Erythropoietin stimulating agents used also as adjuvant to treat chemotherapy-induced anemia may be prohypertensvive as they increase erythrocyte mass and blood viscosity and direct vasopressor effect [46-48].

\section{VEGFR AND HYPERTENSION}

VEGF is crucial in vascular homeostasis. It mediates the synthesis of the vasodilator nitric oxide, and generation of new blood vessel leading to decreased vascular resistance [49-53]. This role of VEGF is associated with decline in blood pressure. Therefore, inhibition of VEGF signaling could lead to development or worsening of preexisting hypertension [54, 55]. VEGF signaling inhibitor induced elevation in blood pressure appears to be not an adverse event of the therapy, but rather a mechanism-dependent on-target toxicity [56]. Taking these data into consideration, all trials evaluating inhibitors of angiogenesis have restricted eligibility to patients with controlled blood pressure at baseline. All commercially available angiogenesis inhibitors have been implicated in the development of hypertension, including bevacizumab [57-60], aflibercept [61], sorafenib [62], sunitinib [63, 64], pazopanib [65], vandetanib [66], axitinib [62, 67], regorafenib [68], and cabozantinib [69, 70].

However, the pathogenesis of elevated blood pressure in subjects treated with anti-VEGF drugs appears to be associated with multiple pathways so far is not yet fully elucidated. The proposed mechanism is shown on the Figure 1. The pathophysiological mechanism of hypertension induced by anti-angiogenic therapy include increased peripheral vascular resistance together with diminished nitric oxide synthesis in endothelium, an increased synthesis of vasoconstrictive substances, and a decreased density in microvasculature i,e rarefaction. In addition, impaired renal function may also contribute to the development or worsening of hypertension. The mechanism of worsening of kidney function during VEGF-TKI (tyrosine kinase inhibitors) therapy has not been elucidated in details. Inhibition of VEGF by pharmacotherapy results in glomerular, endothelial and

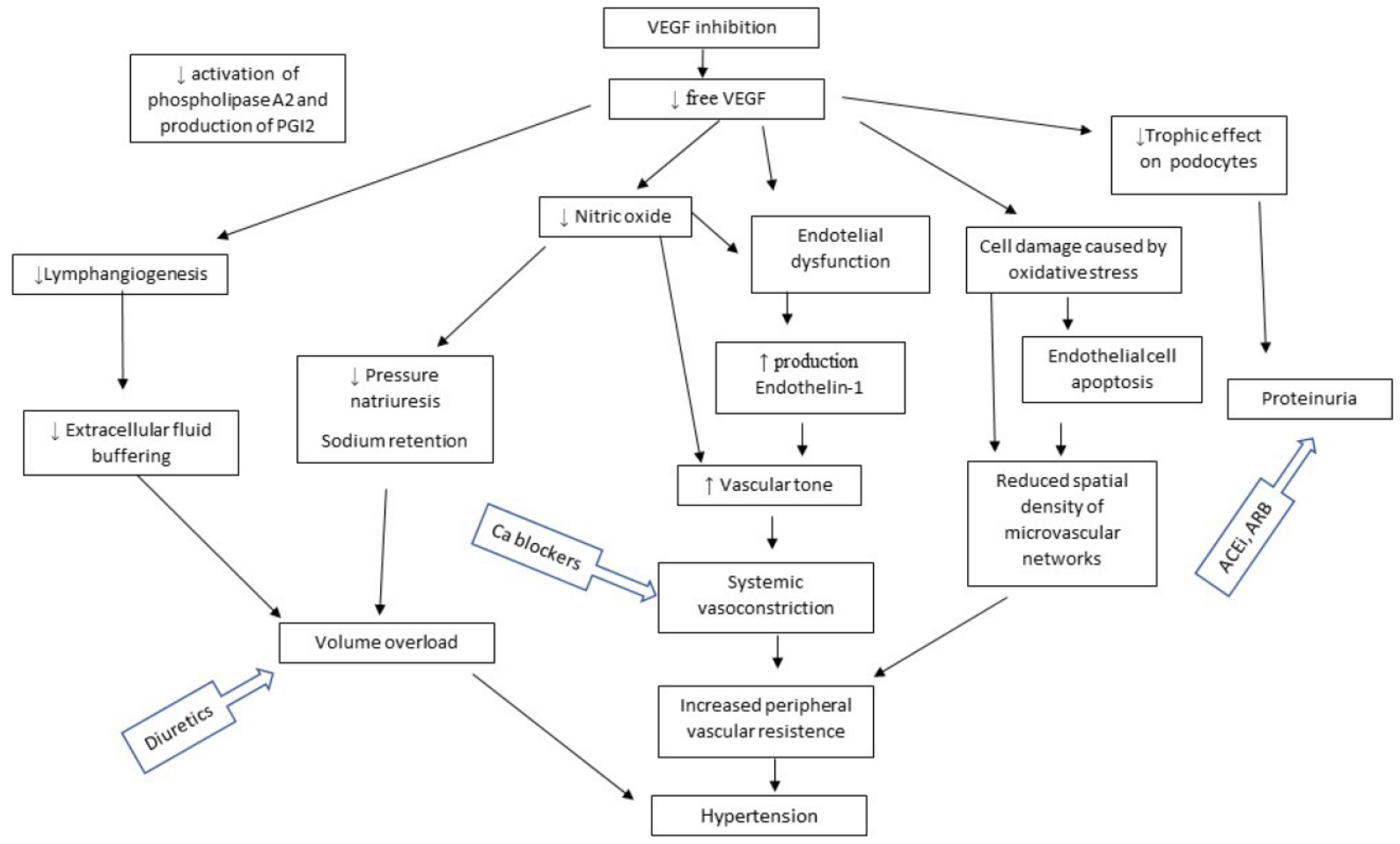

Figure 1: Proposed mechanisms of hypertension induced by anti-VEGF therapy (modified from 128). 
podocyte injury. It may lead to proteinuria as well. In kidney biopsy, the most common were TMA, reflecting vascular damage [71], followed by glomerulonephritis with crescents, focal segmental glomerulosclerosis (FSGS), glomerulonephritis with immune complexes, minimal change disease $(\mathrm{MCN})$, and acute interstitial nephritis [72-76]. In a case of nephropathy, in particular, with impaired kidney function and volume overload, hypertension is common. In addition, therapy with antiVEGF drugs causes vasoconstriction due to diminished synthesis of NO and prostacyclin-PGI2, which leads to impaired blood flow in the glomeruli. It should be also stressed that worsening of kidney function may result from the nephrectomy in RCC subjects as the nephrons loss during nephrectomy either partial or radical is a predisposing factor for chronic kidney disease or development of contrast-induced nephropathy following computed tomography (CT) with contrast media in any malignancy.

\section{Incidence and characteristics}

The study of Miyake et al. [77] reported that hypertension development during sunitinib-therapy predicted good tumor response and significantly longer progression free survival-PFS, but not overall survival$\mathrm{OS}$, in metastatic RCC patients. Furthermore, the incidence of hypertension induced by sunitinib treatment was linked to a longer progression-free survival. Their data are similar to the published reports on hypertensioninduced by bevacizumab and increased PFS [78] and between hypertension induced by axitinib with increased OS [79]. Sire et al. [80] reported that hypertension (grade2-4) developed during first- or second line sunitinib, sorafenib, or bevacizumab therapy for metastatic RCC was a favorable prognostic factor. Moreover, some toxicities caused by sunitinib, such as hypertension and hypothyroidism, as predictors should be tested and validated in well-designed prospective randomized controlled trials.

Bondarenko et al. [81] studied the efficacy and safety of combined therapy including axitinib with cisplatin/ gemcitabine in chemotherapy-naïve subjects with squamous non- small-cell lung cancer (NSCLC) in advanced/metastatic settings (stage IIIB/IV). They reported that most neutropenia and hypertension $(13.2 \%$ each) were the most common grade $\geq 3$ toxicities while hypertension was found in $26.3 \%$, (they excluded patients with uncontrolled hypertension above 140/90 mm Hg). Hypertension as the most common cause for reduction of the dose of axitinib. Anlotinib, a novel multi-target TKI developed to primarily inhibit VEGFR2/3, fibroblast growth factor receptor-FGFR1-4, platelet-derived growth factor receptor-PDGFR $\alpha / \beta$, c-Kit, and Ret. Sun et al. [82] evaluated the anlotinib safety, pharmacokinetics, and antitumor activity in advanced/refractory solid tumors.
They reported that hypertension was the main serious adverse effect. Sulfatinib (HMPL012) is a potent small molecule TKI of VEGFR 1, 2, and 3, FGFR 1, and Colony Stimulating Factor 1 Receptor- CSF1R. Xu et al. [83] investigated the sulfatinib safety, pharmacokinetics, and preliminary antitumor activity in advanced solid tumors. As for other anti-angiogenic drug the most frequent side effects during therapy were proteinuria, hypertension and diarrhea.

Mittal et al. [84] studied a combination of bevacizumab- VEGF antibody, and sunitinib- inhibitor of VEGFR, in patients with advanced solid tumors. Grade 3 or higher side effects, such as hypertension was observed in $41 \%$. In addition, in 18\% TMA was reported. Development of TMA associated with dual VEGF/VEGFR inhibition could be due to systemic or kidney injury even in malignances of non-renal origin. Similarly, when sorafenib was combined with bevacizumab in heavily pretreated subjects with advanced solid tumors, this therapy was associated with hypertension and hand-foot syndrome. However, development of hypertension (grade 3 and 4) was associated with longer time to therapy failure, OS, and higher response rate. In subjects with metastatic melanoma with the ECOG- Eastern Cooperative Oncology Group performance status $0-1$ and normal organ function in a prospective phase II trial therapy with axitinib followed by paclitaxel/carboplatin resulted in development of hypertension in $41 \%$, grade 3 hypertension was observed in $16 \%$. [85]. In the study of Tomita et al. [86] axitinib was administered to Japanese $(n=) 44$ and non-Japanese $(n=169)$ patients with metastatic RCC, which were treatment-naïve. The most frequent side effects in both populations were hypertension and diarrhea. However, most common adverse events, such as hypertension and proteinuria, were more prevalent in Japanese subjects, who also received more often hypotensive medications (95\% in Japanese patients vs. $64 \%$ in non-Japanese patients). In patients with RCC, treatment with pazopanib and sunitinib resulted in a similar incidence of hypertension (46\% vs 41\%), however axitinib caused more hypertension more than sorafenib (40 vs $29 \%$ ) $[62,87]$ Ramucirumab was responsible for $8 \%$ of cases of severe hypertension in patients with advanced gastric cancer [88]. Aflibercept given to patients with colorectal cancer was associated with severe hypertension in $19.1 \%$ of cases [61]. It appears that levantinib was associated with the significantly high rate of both hypertension (68\%) and severe hypertension (42\%) [89]. An et al. [90] published a meta-analysis, which included 12,949 patients with advanced solid tumors treated with or without bevacizumab. They found that the relative risk (RR) of development or worsening of hypertension (defined as more than 1 hypotensive drug used, or for a more intensive therapy than previously, or life-threatening complications such as hypertensive crisis; grade 3 or 4 among patients receiving bevacizumab was 5.38 (95\% CI 3.63-7.97) and was dose-dependent [90]. Moreover, overall incidence of 
hypertension in bevacizumab-treated patients was $24 \%$ (95\% CI 20-29 percent), whereas significant rise in blood pressure was found in $8 \%$ (95\% CI 6-10 percent). Zhu et al. [91] in another meta-analysis analyzed the incidence of hypertension in 13 prospective studies with 4999 subjects with RCC or other malignancies administered sunitinib. The incidence of hypertension was $22 \%$, while in $7 \%$ hypertension was described as severe. Sunitinib treatment was a significant risk factor for development of severe hypertension (RR 22.72, 95\% CI 4.48-115.29). Similar results yielded a systematic review of 9 prospective studies including 4599 patients treated with sorafenib [92]. Another meta-analysis, which included 18 randomized Phase II and III controlled trials on subjects with solid tumors treated with sorafenib reported that daily sorafenib was responsible for enhanced risk for development of hypertension (all grades) and bleeding relative to the control group [93]. In one more meta-analysis by the same authors, it has been has demonstrated that sunitinib, axitinib, cediranib and regorafenib were also the risk factors for development of hypertension (both all grades and high grade) relative to the control group [94]. On the other hand, in one metaanalysis, pazopanib therapy results in higher incidence of hypertension than sorafenib or sunitinib_(36 versus 23 and $22 \%$, respectively), but similar incidence of severe one (6.5 versus 5.7 and 6.8\%, respectively) [95]. In the other meta-analysis, sorafenib, sunitinib, and trastuzumab, were associated with increased risk for reduced left ventricular ejection fraction and hypertension [96, 97]. In the recent review Kroschinsky et al. [98] stressed that introduction of angiogenetic pathways inhibitors substantially enlarge the armamentarium of targeted therapies. As angiogenesis is also necessary for repair of tissue and regeneration thus, effect of these therapies on vascular system, such as severe adverse effects in a form of thromboembolism, bleeding from gastrointestinal tract or even perforation, de novo or worsening of hypertension, and development of congestive heart failure, compromise antineoplastic efficacy. In the recent systemic review, Semeniuk-Wojtas et al. [99], included 48 eligible phase III and IV prospective clinical trials, meta-analyses and retrospective studies describing the AEs in a form of hypertension or other nephrotoxicity in patients received anti-VEGF drugs. They found that hypertension (any grade) was reported in 17\% - 49.6\% of patients, while proteinuria and elevated serum creatinine were found in $8 \%$ to $73 \%$ and $5 \%$ to $65.6 \%$ of subjects, respectively. Risk factors for rise in blood pressure under VEGFR therapy are prior hypertension, age $\geq 60$ years, and body mass index $(\mathrm{BMI}) \geq 25 \mathrm{~kg} / \mathrm{m}^{2}$ [100]. The significant rise in blood pressure were observed as early as in the first week of treatment [101, 102]. There are several reports that the are some SNPs that are linked with a higher risk for hypertension development during TKI therapy [103, 104]. However, no factors are yet known to predict the magnitude of blood pressure rise [105]. As untreated severe hypertension may lead to serious complications, patients treated with VEGFR inhibitors should have their blood pressure actively monitored during therapy, with more frequent measurement in the first several weeks of the treatment.

\section{Association with antitumor efficacy}

It has been reported that hypertension development was linked with better antitumor efficacy in subjects treated with bevacizumab and the antiangiogenic TKIs [58, 104, 106-112] however, it was not a consistent finding in some studies [113-115]. In 4 prospective studies in patients with advanced RCC treated with sunitinib, rise in blood pressure over $140 \mathrm{~mm} \mathrm{Hg}$ was associated with better antitumor efficacy (median OS, median PFS, and objective response rates were 30.9 versus 7.2 months, 12.5 versus 2.5 months, and 55 versus 9 percent, respectively) [111]. Similar results were seen with rise in diastolic blood pressure over $90 \mathrm{mmHg}$. Moreover, multivariate analysis revealed that sunitinib treatment independently predicted survival (hazard ratio [HR] 0.28, 95\% CI 0.22-0.37). Six clinical studies of sunitinib, sunitinib showed that dose intensity and cumulative weekly dose correlated with both improved clinical outcomes and maximum blood pressure [116]. On the other hand, in 7 randomized trials with bevacizumab used for RCC, colorectal, breast, NSCLC, and pancreatic cancer, no association between early hypertension and clinical benefit from bevacizumab was found [115].

Hence, further studies are warranted to validate hypertension as an efficacy predictor during therapy with angiogenesis inhibitors. It has been reported that hypertension development predicted a better response of the tumor to the therapy with anti-VEGF drugs in some studies [32, 117, 118], therefore, in a case of either hypertension de novo or worsening of the preexisting hypertension, physicians should maintain targeted therapy and use of hypotensive medications to control blood pressure rather than withdraw antineoplastic drugs. However, withdrawal of anti-VEGF treatment should be taken into account in cases when severe adverse events appeared. It should also stressed that treatment with bevacizumab combined with TKIs may result in development of severe hypertension and other lifethreatening toxicities i.e. vascular and hematological $[119,120]$.

\section{Monitoring and management of hypertension}

For most studies and in clinical practice, patients who are actively taking antihypertensive medications are usually defined as having hypertension regardless of their observed blood pressure. There are no data in this aspect. Ambulatory blood pressure monitoring is generally employed in the randomized control trials in hypertension, however, not in every study i.e. SPRINT 
(Systolic Blood Pressure Intervention Trial, ClinicalTrials. gov identifier NCT01206062) where blood pressure was measured by patients in office in the seated position using an automated measurement device (Omron Healthcare, Lake Forest, IL) [121] In some cases of incurable disease, a minimalistic approach to treat elevated blood pressure might be favored, however, treatment of existing comorbidities, with hypertension among them, actually may improve quality of life and survival [116]. Furthermore, appropriate control of blood pressure should allow oncology subjects to cope with the highest effective doses of the treatment, for longest period of time [102]. Patients who develop hypertension during treatment (by definition as blood pressure $\geq 140 / 90 \mathrm{mmHg}$ or a $20 \mathrm{~mm}$ increase in diastolic blood pressure over baseline) should be treated with antihypertensives. Target blood pressure is below 140/90 mm $\mathrm{Hg}$ or even lower in case of over proteinuria according to current guidelines (ESH/ESCEuropean Society of Hypertension/European Society of Cardiology, AHA-American Heart Association, JNC8-Joint National Committee) [122-124]. However, according to new AHA guidelines hypertension stage 1 is diagnosed when systolic blood pressure is between 130 to $139 \mathrm{mmHg}$ or diastolic blood pressure is between 80 to $89 \mathrm{mmHg}$, stage 2 is defined when systolic blood pressure is at least $140 \mathrm{mmHg}$ or diastolic blood pressure is at least $90 \mathrm{mmHg}$ on 2 or more properly measured readings at each of 2 or more office visits after an initial screening [31]. Organ dysfunction and/or adverse effects on organ function may influence the choice and dose of the antihypertensive agent [125]. The choice of agent must also take into consideration the severity of the hypertension and the urgency of blood pressure control. In addition, several other considerations may influence the choice of antihypertensive therapy. For patients who develop hypertension while receiving treatment with an antiangiogenic agent, blood pressure should be monitored actively during the therapy. More frequent measurements in the first several weeks of treatment are prerequisite. Only this group of patients have recommendations in 2016 ESC Position Paper on cancer treatments and cardiovascular toxicity, which was published under the auspices of the ESC Committee for Practice Guidelines [126]. In these patients, treatment with angiotensin system inhibitors (ASIs; eg, angiotensin converting enzyme inhibitors [ACEIs], angiotensin receptor blockers [ARBs]) may be preferred over other drugs. In subjects treated with VEGF inhibitors, when diarrhea is observed as a side effect, diuretics should not be given as first line hypotensive therapy. As sorafenib and sunitinib undergo partial metabolism via cytochrome P450, a system inhibited by some antihypertensive agents (eg, verapamil, diltiazem) [54], therefore, these agents should probably be avoided in patients who develop hypertension while receiving sorafenib or sunitinib. In patients treated with cardiotoxic chemotherapy, who are considered
Stage A Heart Failure (HF) [127], the most effective agents are generally considered to be those that are also effective at preventing adverse cardiac remodeling, including ACEis, beta-blockers, or ARBs. ACEi and beta-blockers are preferred as hypotensives in subjects with HF, left ventricular dysfunction or at risk of HF. Valuable option could be nebivolol (beta1-blocker) due to its properties affecting cell NO signaling or carvedilol with its vasodilation properties. Phosphodiesterase 5 inhibitors such as sildenafil or tadalafil may be taken into account, however, data on the efficacy are limited in this setting. Diuretics may lead to electrolyte disturbances and consequent QT prolongation, thus should be used cautiously. Beta-blockers and ACE inhibitors may be administered together with trastuzumab as prophylactic agents in patients with breast cancer as tolerated. Cardiac function could recover early after the injury caused by cancer treatment. It appears that late complications for ischemic heart disease, hypertension and rhythm disturbances are underappreciated. However, therapy of severe cardiotoxicity related to cancer treatment follow paradigms, which exist for chronic HF and ischemic heart disease, however outcomes for subjects with malignancy are different from those outcomes reported for general population. In a case of severe hypertension, close monitoring and adherence to therapy is strongly recommended. Ambulatory blood pressure monitoring is to be considered in certain cases, especially treated with VEGFR inhibitors, particularly in the first weeks of the therapy. It is also of utmost importance to assess the efficacy and tolerability of hypotensive treatment. Resistant hypertension, which is defined as inability to reach target blood pressure despite three hypotensive drugs including diuretic in adequate doses require consult of cardiooncology or hypertension specialist in order to minimize the intervals in the VEGF inhibitors therapy. Although VEGF signaling pathway inhibitors (anti-angiogenic therapy) are strongly associated with hypertension and cardiovascular dysfunction during therapy [128-131], the long-term effects of these agents remain undefined. Patients who developed hypertension during anti-VEGR therapy should continue with this antineoplastic treatment due to suggested potential clinical benefits and start antihypertensive drugs to control blood pressure. Thus, The Investigational Drug Steering Committee of the National Cancer Institute formed a Cardiovascular Toxicities Panel, joining members of its Angiogenesis Task Force with experts in the treatment of hypertension in oncology patients, developed consensus recommendations for risk assessment, monitoring, and safe administration of angiogenesis inhibitors [105]. They recommend to perform a pretreatment evaluation and screening, with formal risk assessment for potential cardiovascular complications to identify and treat preexisting hypertension before using these agents. They also stress that is it is crucial to adequately control 
pain and stress. Other drugs that may influence blood pressure control such as glucocorticosteroids, nonsteroidal antiinflammatory drugs, erythropoietin stimulating agents should be also taken into account. Judicious blood pressure control and aggressive cardiovascular risk factor modification are important guiding principles. Antihypertensive therapy is crucial to manage hypertension during certain chemotherapy and those agents known to prevent HF are preferred. In addition, it has been also suggested that in patients with high risk of cardiotoxicity, aggressive treatment of preexisting hypertension should be employed as suggested by Carver et al. [132].

\section{Possible influence of some cardiovascular drugs on cancer treatment}

Cancer is associated with increased risk of thromboembolic events. Aki et al. [133] in the Cochrane Database systemic reviews concluded that heparin appeared to have no effect on mortality in cancer patients. Anticoagulation reduced the incidence of symptomatic thromboembolic events together with increased incidence of bleeding. In the recent study by Uppuluri et al. [134], direct acting anticoagulants-DOACs were reported to be as safe and effective as low molecular weight heparinsLMWH in cancer subjects with thromboembolism. Similar data were reported by others [135-137]. Melloni et al. [138]. in the ARISTOTLE trial (Apixaban for Reduction in Stroke and Other Thromboembolic Events in Atrial Fibrillation) assessed the effects and safety of apixaban vs warfarin in subjects with atrial fibrillation and history of malignancy. In this study, prior cancer was not associated with higher stroke risk. In addition, in patients with history of malignancy apixaban appeared superior to warfarin in regard to the efficacy and safety. Maraveyos et al. [139] showed in oncology patients an encouraging data on the use of DOACs in cancer-associated thrombosis, but they stated that LMWH remained a standard anticoagulation in this set of patients. Haaland et al. [140] studied the association between use of warfarin and cancer in subgroup of patients from Norwegian National Registry coupled with the Norwegian Prescription Database and the Cancer Registry of Norway. They found that warfarin users had a significantly lower age- and sexadjusted IRR-incidence rate ratio in all cancer sites and in prevalent organ-specific sites such as lung, prostate and breast when compared to nonusers. They concluded that warfarin use in patients over 50 years of age may yield additional benefit when there was a necessity of anticoagulation. However, we should bear in mind that dose of all anticoagulant, in particular of DOACs should be adjusted to kidney function [141]. Some DOACs are to be avoided in end-stage kidney disease, in this setting LMWH or warfarin should be considered. It has been shown that low dose acetylsalicylic acid -ASA may have a potentially beneficial effect in cardiovascular disease primary prevention in cancer patients in term of mortality [142]. However, possible side effects such as bleeding should be considered before introduction of ASA as a chemopreventive modality [143]. In 2016, the US Preventive Services Task Force recommended to start ASA as cardiovascular disease and colorectal cancer primary prevention among subjects 50-59 years of age being at increased risk for cardiovascular disease. [142]. In addition, Matsuo et al. [144] reported that low-dose aspirin in endometrial cancer contribute to the improved survival outcomes, in particular, in young, obese, with low-grade disease, with postoperative radiotherapy.

Metformin is widely used to treat type 2 diabetes. However, metformin may act also on the different pathway i.e. may activate of LKB1 (liver kinase B1)/ AMPK (5'AMP-activated protein kinase) pathway, inhibit of cell division and/or promotion of apoptosis, promote of autophagy, down-regulate circulating insulin, activate the immune system and inhibit mTOR dependent pathways and thereby exert antineoplastic properties [145-147] [145-147]. In several studies, it has been shown that metformin lowers cancer mortality when compared with either nonusers or use of other hypoglycemic drugs [148-152]. In cervical cancer metformin use was associated with improved PSF, but not in OS in diabetic patients with this cancer [153]. In addition, metformin use was reported to be associated with a lower risk of developing head and neck cancer in diabetic patients [154] but not of RCC [155].

\section{SUMMARY}

Cardiovascular status is prerequisite to introduce certain anticancer therapy and on the other hand, effects of chemotherapy and targeted drug treatment are extremely important to cancer survivors in regard to the overall health and quality of life. Hypertension is a common comorbidity in patients with malignancy, especially in elderly population. Hypertension as a comorbidity in cancer patients was not thoroughly investigated. Some cancers may cause secondary hypertension mainly due to loss of kidney function after nephrectomy. Both chemotherapy and targeted therapy may be associated with development or worsening of preexisting hypertension. Several drugs such as cisplatin derivatives, mTOR inhibitors, anthracyclines, alkylating agents may cause hypertension. VEGFR inhibitors are the most common targeted drugs associated with hypertension as a side effect of the therapy. However, data concerning antitumor activity and hypertension are inconsistent. Problem of hypertension induced by anticancer treatment is vital because new agents, especially targeting VEGF pathway, are used frequently to treat common malignancies. Additionally, cancer patients are not always in a 
comprehensive cancer centers with specialists managing both the malignancy and other adverse events resulting either from the cancer or its therapy. In particular, in rural or small urban areas, oncological patients are often treated or co-treated by a primary care physician with help from a medical oncologist that may be quite far away. As shown previously, Charlson Comorbidity Index with hypertension included significantly predicted survival from all causes $(\mathrm{HR}=1.32,95 \% \mathrm{CI} 1.18-1.49)$, competing causes $(\mathrm{HR}=1.52,95 \% \mathrm{CI} 1.32-1.76)$ and breast cancer specific causes $(\mathrm{HR}=1.18,95 \% \mathrm{CI} 1.03-1.35)$ [156]. The authors concluded that as hypertension has prognostic significance it may be necessary to introduce hypertension-augmented Charlson Comorbidity Index and include other comorbidities to this index. There are no substantial long-term data is available and guidelines for a special therapeutic strategy in cancer patients. In regard, to the management of hypertension in malignancy, meticulous attention should be paid to pretreatment screening for risk factors. In daily clinical practice, the initial treatment usually include drug affecting reninangiotensin aldosterone system i.e. ACE inhibitor or $\mathrm{ARB}$, or a long-acting calcium channel blocker-CCB most often amlodipine. The most common dual combination regimen to reach the target blood pressure consist of $\mathrm{ACE}$ inhibitor or $\mathrm{ARB}$ and either a long-acting-CCB or thiazide diuretic. In three drug therapy the preferred regimen consists of ACE inhibitor or ARB with a longacting $\mathrm{CCB}$ and a diuretic. In subjects with at least stage 4 of CKD i.e. an estimated glomerular filtration-eGFR rate of less than $30 \mathrm{~mL} / \mathrm{min}$ per $1.73 \mathrm{~m}^{2}$, a loop diuretic, such as furosemide or torsemide, is added for effective volume control. In the recent paper from Journal of American College of Cardiology (14th Nov) only a small section with very limited data is devoted to the hypertension [157]. A recently published survey revealed that almost all medical oncologists administered cardiotoxic treatments, including anthracyclines (83\%), trastuzumab (51\%) and other antiangiogenic drugs (64\%) [158]. Only 35\% of oncologists managed cardiotoxicity on the basis of the guidelines from expert oncology societies, whereas recommendations from expert cardiology societies was virtually not known. In addition, the treatment of hypertension was not consistent. The authors concluded that oncology practices are disparate in the area of cardiotoxicity.

Therefore, wrapping up, as the aging population increases both the risk of hypertension and cancer, thus urgent need for cooperation between oncologists, cardiologists, nephrologists or hypertension specialists to effectively manage cancer patients with hypertension as a comorbidity or a complication of the therapy. Researchers should at first assess the epidemiology of hypertension in cancer patients, then look at the possible influence of history of hypertension on development of serious side effects and outcomes, and whether appropriate and timely therapy affect survival and quality of life.

\section{CONFLICTS OF INTEREST}

None.

\section{REFERENCES}

1. American Cancer Society. Cancer Treatment and Survivorship Facts \& Figures 2015-2016. American Cancer Society; Atlanta, GA 2016.

2. World estimated cancer prevalence, adult population: both sexes. http://globocan.iarc.fr/summary_table_site_prev.asp ? selection $=280 \&$ title $=$ All + cancers + excl. + non-melanom $\mathrm{a}+$ skin + cancer \&se $=0$ \&africa $=1$ \&america $=2 \&$ asia $=3 \&$ e urope $=4 \&$ oceania $=5 \&$ build $=6 \&$ window $=1 \&$ sort $=15 \&$ submit=\%A0Execute\%A0 (Accessed on September 27, 2017).

3. Lenihan DJ, Cardinale DM. Late cardiac effects of cancer treatment. J Clin Oncol. 2012; 30:3657-64. https://doi. org/10.1200/JCO.2012.45.2938.

4. van Laar M, Feltbower RG, Gale CP, Bowen DT, Oliver SE, Glaser A. Cardiovascular sequelae in long-term survivors of young peoples' cancer: a linked cohort study. Br J Cancer. 2014; 110:1338-41. https://doi.org/10.1038/bjc.2014.37.

5. Aapro M, Bernard-Marty C, Brain EG, Batist G, Erdkamp F, Krzemieniecki K, Leonard R, Lluch A, Monfardini S, Ryberg M, Soubeyran P, Wedding U. Anthracycline cardiotoxicity in the elderly cancer patient: a SIOG expert position paper. Ann Oncol. 2011; 22:257-67. https://doi. org/10.1093/annonc/mdq609.

6. Mouhayar E, Salahudeen A. Hypertension in cancer patients. Tex Heart Inst J. 2011; 38:263-5.

7. Albini A, Pennesi G, Donatelli F, Cammarota R, De Flora S, Noonan DM. Cardiotoxicity of anticancer drugs: the need for cardio-oncology and cardio-oncological prevention. J Natl Cancer Inst. 2010; 102:14-25. https://doi.org/10.1093/ jnci/djp440.

8. Schmidinger M, Zielinski CC, Vogl UM, Bojic A, Bojic M, Schukro C, Ruhsam M, Hejna M, Schmidinger H. Cardiac toxicity of sunitinib and sorafenib in patients with metastatic renal cell carcinoma. J Clin Oncol. 2008; 26:5204-12. https://doi.org/10.1200/JCO.2007.15.6331.

9. Mellor HR, Bell AR, Valentin JP, Roberts RR. Cardiotoxicity associated with targeting kinase pathways in cancer. Toxicol Sci. 2011; 120:14-32. https://doi. org/10.1093/toxsci/kfq378.

10. Chu TF, Rupnick MA, Kerkela R, Dallabrida SM, Zurakowski D, Nguyen L, Woulfe K, Pravda E, Cassiola F, Desai J, George S, Morgan JA, Harris DM, et al. Cardiotoxicity associated with tyrosine kinase inhibitor sunitinib. Lancet. 2007; 370:2011-9. https://doi.org/10.1016/ S0140-6736(07)61865-0. 
11. Girardi F, Franceschi E, Brandes AA. Cardiovascular safety of VEGF-targeting therapies: current evidence and handling strategies. Oncologist. 2010; 15:683-94. https:// doi.org/10.1634/theoncologist.2009-0235.

12. Di Lorenzo G, Autorino R, Bruni G, Carteni G, Ricevuto E, Tudini M, Ficorella C, Romano C, Aieta M, Giordano A, Giuliano M, Gonnella A, De Nunzio C, et al. Cardiovascular toxicity following sunitinib therapy in metastatic renal cell carcinoma: a multicenter analysis. Ann Oncol. 2009; 20:1535-42. https://doi.org/10.1093/annonc/mdp025.

13. Haugnes HS, Wethal $\mathrm{T}$, Aass $\mathrm{N}$, Dahl O, Klepp O, Langberg CW, Wilsgaard T, Bremnes RM, Fossa SD. Cardiovascular risk factors and morbidity in long-term survivors of testicular cancer: a 20 -year follow-up study. J Clin Oncol. 2010; 28:4649-57. https://doi.org/10.1200/ JCO.2010.29.9362.

14. Sagstuen H, Aass N, Fossa SD, Dahl O, Klepp O, Wist EA, Wilsgaard T, Bremnes RM. Blood pressure and body mass index in long-term survivors of testicular cancer. $\mathrm{J}$ Clin Oncol. 2005; 23:4980-90. https://doi.org/10.1200/ JCO.2005.06.882.

15. Travis LB, Beard C, Allan JM, Dahl AA, Feldman DR, Oldenburg J, Daugaard G, Kelly JL, Dolan ME, Hannigan R, Constine LS, Oeffinger KC, Okunieff P, et al. Testicular cancer survivorship: research strategies and recommendations. J Natl Cancer Inst. 2010; 102:1114-30. https://doi.org/10.1093/jnci/djq216.

16. Tothill P, Klys HS, Matheson LM, McKay K, Smyth JF. The long-term retention of platinum in human tissues following the administration of cisplatin or carboplatin for cancer chemotherapy. Eur J Cancer. 1992; 28A:1358-61.

17. Gietema JA, Meinardi MT, Messerschmidt J, Gelevert T, Alt F, Uges DR, Sleijfer DT. Circulating plasma platinum more than 10 years after cisplatin treatment for testicular cancer. Lancet. 2000; 355:1075-6.

18. Kirchmair R, Walter DH, Ii M, Rittig K, Tietz AB, Murayama T, Emanueli C, Silver M, Wecker A, Amant C, Schratzberger P, Yoon YS, Weber A, et al. Antiangiogenesis mediates cisplatin-induced peripheral neuropathy: attenuation or reversal by local vascular endothelial growth factor gene therapy without augmenting tumor growth. Circulation. 2005; 111:2662-70. https://doi.org/10.1161/ CIRCULATIONAHA.104.470849.

19. Jansson T, Persson E. Placental transfer of glucose and amino acids in intrauterine growth retardation: studies with substrate analogs in the awake guinea pig. Pediatr Res. 1990; 28:2038. https://doi.org/10.1203/00006450-199009000-00007.

20. El-Awady el-SE, Moustafa YM, Abo-Elmatty DM, Radwan A. Cisplatin-induced cardiotoxicity: Mechanisms and cardioprotective strategies. Eur J Pharmacol. 2011; 650:335-41. https://doi.org/10.1016/j.ejphar.2010.09.085.

21. Chari A, Hajje D. Case series discussion of cardiac and vascular events following carfilzomib treatment: possible mechanism, screening, and monitoring. BMC Cancer. 2014; 14:915. https://doi.org/10.1186/1471-2407-14-915.
22. Armenian SH, Lacchetti C, Barac A, Carver J, Constine LS, Denduluri N, Dent S, Douglas PS, Durand JB, Ewer M, Fabian C, Hudson M, Jessup M, et al. Prevention and Monitoring of Cardiac Dysfunction in Survivors of Adult Cancers: American Society of Clinical Oncology Clinical Practice Guideline. J Clin Oncol. 2017; 35:893-911. https:// doi.org/10.1200/JCO.2016.70.5400.

23. Von Hoff DD, Layard MW, Basa P, Davis HL Jr, Von Hoff AL, Rozencweig M, Muggia FM. Risk factors for doxorubicin-induced congestive heart failure. Ann Intern Med. 1979; 91:710-7.

24. Hequet O, Le QH, Moullet I, Pauli E, Salles G, Espinouse D, Dumontet C, Thieblemont C, Arnaud P, Antal D, Bouafia F, Coiffier B. Subclinical late cardiomyopathy after doxorubicin therapy for lymphoma in adults. J Clin Oncol. 2004; 22:1864-71. https://doi.org/10.1200/JCO.2004.06.033.

25. Jain M, Townsend RR. Chemotherapy agents and hypertension: a focus on angiogenesis blockade. Curr Hypertens Rep. 2007; 9:320-8.

26. Hershman DL, McBride RB, Eisenberger A, Tsai WY, Grann VR, Jacobson JS. Doxorubicin, cardiac risk factors, and cardiac toxicity in elderly patients with diffuse B-cell non-Hodgkin's lymphoma. J Clin Oncol. 2008; 26:3159-65. https://doi.org/10.1200/JCO.2007.14.1242.

27. Pinder MC, Duan Z, Goodwin JS, Hortobagyi GN, Giordano SH. Congestive heart failure in older women treated with adjuvant anthracycline chemotherapy for breast cancer. J Clin Oncol. 2007; 25:3808-15. https://doi. org/10.1200/JCO.2006.10.4976.

28. Szmit S, Jurczak W, Zaucha JM, Drozd-Sokolowska J, Spychalowicz W, Joks M, Dlugosz-Danecka M, Torbicki A. Pre-existing arterial hypertension as a risk factor for early left ventricular systolic dysfunction following (R)-CHOP chemotherapy in patients with lymphoma. J Am Soc Hypertens. 2014; 8:791-9. https://doi.org/10.1016/j. jash.2014.08.009.

29. Russo G, Cioffi G, Gori S, Tuccia F, Boccardi L, Khoury G, Lestuzzi C, Maurea N, Oliva S, Faggiano P, Tarantini L; ICARO (Italian CARdio-Oncological) Network. Role of hypertension on new onset congestive heart failure in patients receiving trastuzumab therapy for breast cancer. J Cardiovasc Med (Hagerstown). 2014; 15:141-6. https://doi. org/10.2459/JCM.0b013e328365afb5.

30. Mantarro S, Rossi M, Bonifazi M, D'Amico R, Blandizzi C, La Vecchia C, Negri E, Moja L. Risk of severe cardiotoxicity following treatment with trastuzumab: a meta-analysis of randomized and cohort studies of 29,000 women with breast cancer. Intern Emerg Med. 2016; 11:123-40. https://doi.org/10.1007/s11739-015-1362-x.

31. Whelton PK, Carey RM, Aronow WS, Casey DE Jr, Collins KJ, Dennison Himmelfarb C, DePalma SM, Gidding S, Jamerson KA, Jones DW, MacLaughlin EJ, Muntner P, Ovbiagele B, et al. 2017 ACC/AHA/AAPA/ABC/ACPM/ AGS/APhA/ASH/ASPC/NMA/PCNA Guideline for the Prevention, Detection, Evaluation, and Management of 
High Blood Pressure in Adults: A Report of the American College of Cardiology/American Heart Association Task Force on Clinical Practice Guidelines. Hypertension. 2017 Nov 13. https://doi.org/10.1161/HYP.0000000000000065. [Epub ahead of print].

32. Li Y, Li S, Zhu Y, Liang X, Meng H, Chen J, Zhang D, Guo H, Shi B. Incidence and risk of sorafenib-induced hypertension: a systematic review and meta-analysis. J Clin Hypertens (Greenwich). 2014; 16:177-85. https://doi. org/10.1111/jch.12273.

33. Eremina V, Jefferson JA, Kowalewska J, Hochster H, Haas M, Weisstuch J, Richardson C, Kopp JB, Kabir MG, Backx $\mathrm{PH}$, Gerber HP, Ferrara N, Barisoni L, et al. VEGF inhibition and renal thrombotic microangiopathy. N Engl J Med. 2008; 358:1129-36. https://doi.org/10.1056/NEJMoa0707330.

34. Glezerman I, Kris MG, Miller V, Seshan S, Flombaum CD. Gemcitabine nephrotoxicity and hemolytic uremic syndrome: report of 29 cases from a single institution. Clin Nephrol. 2009; 71:130-9.

35. Motzer RJ, Escudier B, Oudard S, Hutson TE, Porta C, Bracarda S, Grunwald V, Thompson JA, Figlin RA, Hollaender N, Kay A, Ravaud A, Group RS. Phase 3 trial of everolimus for metastatic renal cell carcinoma : final results and analysis of prognostic factors. Cancer. 2010; 116:4256-65. https://doi.org/10.1002/cncr.25219.

36. Hudes G, Carducci M, Tomczak P, Dutcher J, Figlin R, Kapoor A, Staroslawska E, Sosman J, McDermott D, Bodrogi I, Kovacevic Z, Lesovoy V, Schmidt-Wolf IG, et al. Temsirolimus, interferon alfa, or both for advanced renalcell carcinoma. N Engl J Med. 2007; 356:2271-81. https:// doi.org/10.1056/NEJMoa066838.

37. Fasolo A, Sessa C. Targeting mTOR pathways in human malignancies. Curr Pharm Des. 2012; 18:2766-77.

38. Houde VP, Brule S, Festuccia WT, Blanchard PG, Bellmann K, Deshaies Y, Marette A. Chronic rapamycin treatment causes glucose intolerance and hyperlipidemia by upregulating hepatic gluconeogenesis and impairing lipid deposition in adipose tissue. Diabetes. 2010; 59:1338-48. https://doi.org/10.2337/db09-1324.

39. Schonenberger E, Ehrich JH, Haller H, Schiffer M. The podocyte as a direct target of immunosuppressive agents. Nephrol Dial Transplant. 2011; 26:18-24. https://doi. org/10.1093/ndt/gfq617.

40. Mangray M, Vella JP. Hypertension after kidney transplant. Am J Kidney Dis. 2011; 57:331-41. https://doi. org/10.1053/j.ajkd.2010.10.048.

41. Kaplan B, Qazi Y, Wellen JR. Strategies for the management of adverse events associated with mTOR inhibitors. Transplant Rev (Orlando). 2014; 28:126-33. https://doi. org/10.1016/j.trre.2014.03.002.

42. Senkus E, Jassem J. Cardiovascular effects of systemic cancer treatment. Cancer Treat Rev. 2011; 37:300-11. https://doi.org/10.1016/j.ctrv.2010.11.001.

43. Floyd JD, Nguyen DT, Lobins RL, Bashir Q, Doll DC, Perry MC. Cardiotoxicity of cancer therapy. J Clin Oncol. 2005; 23:7685-96. https://doi.org/10.1200/JCO.2005.08.789.
44. Souza VB, Silva EN, Ribeiro ML, Martins Wde A. Hypertension in patients with cancer. Arq Bras Cardiol. 2015; 104:246-52. https://doi.org/10.5935/abc.20150011.

45. Dimopoulos MA, Moreau P, Palumbo A, Joshua D, Pour L, Hajek R, Facon T, Ludwig H, Oriol A, Goldschmidt H, Rosinol L, Straub J, Suvorov A, et al. Carfilzomib and dexamethasone versus bortezomib and dexamethasone for patients with relapsed or refractory multiple myeloma (ENDEAVOR): a randomised, phase 3, open-label, multicentre study. Lancet Oncol. 2016; 17:27-38. https://doi. org/10.1016/S1470-2045(15)00464-7.

46. Falkson CI, Keren-Rosenberg S, Uys A, Falkson G, Stevens $\mathrm{K}$, Vermaak WJ. Recombinant human erythropoietin in the treatment of cancer-related anaemia. Oncology. 1994; 51:497-501.

47. Chiou TJ, Chim YS, Wei CH, Hsieh RK, Chen PM. The effect of subcutaneous $r-H u E P O$ in cancer patients receiving chemotherapy with anemia: a preliminary report. Zhonghua Yi Xue Za Zhi (Taipei). 1997; 60:229-35.

48. Dicato M, Plawny L. Erythropoietin in cancer patients: pros and cons. Curr Opin Oncol. 2010; 22:307-11. https://doi. org/10.1097/CCO.0b013e32833aa9de.

49. Henry TD, Annex BH, McKendall GR, Azrin MA, Lopez JJ, Giordano FJ, Shah PK, Willerson JT, Benza RL, Berman DS, Gibson CM, Bajamonde A, Rundle AC, et al. The VIVA trial: Vascular endothelial growth factor in Ischemia for Vascular Angiogenesis. Circulation. 2003; 107:1359-65.

50. Hood JD, Meininger CJ, Ziche M, Granger HJ. VEGF upregulates ecNOS message, protein, and NO production in human endothelial cells. Am J Physiol. 1998; 274:H1054-8.

51. Madeddu P. Therapeutic angiogenesis and vasculogenesis for tissue regeneration. Exp Physiol. 2005; 90:315-26. https://doi.org/10.1113/expphysiol.2004.028571.

52. Carmeliet P. Manipulating angiogenesis in medicine. J Intern Med. 2004; 255:538-61. https://doi. org/10.1111/j.1365-2796.2003.01297.x.

53. Robinson ES, Khankin EV, Choueiri TK, Dhawan MS, Rogers MJ, Karumanchi SA, Humphreys BD. Suppression of the nitric oxide pathway in metastatic renal cell carcinoma patients receiving vascular endothelial growth factorsignaling inhibitors. Hypertension. 2010; 56:1131-6. https:// doi.org/10.1161/HYPERTENSIONAHA.110.160481.

54. Sica DA. Angiogenesis inhibitors and hypertension: an emerging issue. J Clin Oncol. 2006; 24:1329-31. https:// doi.org/10.1200/JCO.2005.04.5740.

55. Izzedine H, Ederhy S, Goldwasser F, Soria JC, Milano G, Cohen A, Khayat D, Spano JP. Management of hypertension in angiogenesis inhibitor-treated patients. Ann Oncol. 2009; 20:807-15. https://doi.org/10.1093/annonc/mdn713.

56. Simons M, Eichmann A. "On-target” cardiac effects of anticancer drugs: lessons from new biology. J Am Coll Cardiol. 2012; 60:626-7. https://doi.org/10.1016/j. jacc.2012.01.069.

57. Hurwitz H, Fehrenbacher L, Novotny W, Cartwright T, Hainsworth J, Heim W, Berlin J, Baron A, Griffing 
S, Holmgren E, Ferrara N, Fyfe G, Rogers B, et al. Bevacizumab plus irinotecan, fluorouracil, and leucovorin for metastatic colorectal cancer. N Engl J Med. 2004; 350:2335-42. https://doi.org/10.1056/NEJMoa032691.

58. Mir O, Coriat R, Cabanes L, Ropert S, Billemont B, Alexandre J, Durand JP, Treluyer JM, Knebelmann B, Goldwasser F. An observational study of bevacizumabinduced hypertension as a clinical biomarker of antitumor activity. Oncologist. 2011; 16:1325-32. https://doi. org/10.1634/theoncologist.2010-0002.

59. Shah SR, Gressett Ussery SM, Dowell JE, Marley E, Liticker J, Arriaga Y, Verma U. Shorter bevacizumab infusions do not increase the incidence of proteinuria and hypertension. Ann Oncol. 2013; 24:960-5. https://doi. org/10.1093/annonc/mds593.

60. Totzeck M, Mincu RI, Rassaf T. Cardiovascular Adverse Events in Patients With Cancer Treated With Bevacizumab: A Meta-Analysis of More Than 20000 Patients. J Am Heart Assoc. 2017; 6. https://doi.org/10.1161/JAHA.117.006278.

61. Van Cutsem E, Tabernero J, Lakomy R, Prenen H, Prausova J, Macarulla T, Ruff P, van Hazel GA, Moiseyenko V, Ferry D, McKendrick J, Polikoff J, Tellier A, et al. Addition of aflibercept to fluorouracil, leucovorin, and irinotecan improves survival in a phase III randomized trial in patients with metastatic colorectal cancer previously treated with an oxaliplatin-based regimen. J Clin Oncol. 2012; 30:3499506. https://doi.org/10.1200/JCO.2012.42.8201.

62. Rini BI, Escudier B, Tomczak P, Kaprin A, Szczylik C, Hutson TE, Michaelson MD, Gorbunova VA, Gore ME, Rusakov IG, Negrier S, Ou YC, Castellano D, et al. Comparative effectiveness of axitinib versus sorafenib in advanced renal cell carcinoma (AXIS): a randomised phase 3 trial. Lancet. 2011; 378:1931-9. https://doi.org/10.1016/ S0140-6736(11)61613-9.

63. Veronese ML, Mosenkis A, Flaherty KT, Gallagher M, Stevenson JP, Townsend RR, O'Dwyer PJ. Mechanisms of hypertension associated with BAY 43-9006. J Clin Oncol. 2006; 24:1363-9. https://doi.org/10.1200/ JCO.2005.02.0503

64. Bamias A, Manios E, Karadimou A, Michas F, Lainakis G, Constantinidis C, Deliveliotis C, Zakopoulos N, Dimopoulos MA. The use of 24-h ambulatory blood pressure monitoring (ABPM) during the first cycle of sunitinib improves the diagnostic accuracy and management of hypertension in patients with advanced renal cancer. Eur J Cancer. 2011; 47:1660-8. https://doi.org/10.1016/j. ejca.2011.03.033.

65. Sternberg CN, Davis ID, Mardiak J, Szczylik C, Lee E, Wagstaff J, Barrios CH, Salman P, Gladkov OA, Kavina A, Zarba JJ, Chen M, McCann L, et al. Pazopanib in locally advanced or metastatic renal cell carcinoma: results of a randomized phase III trial. J Clin Oncol. 2010; 28:1061-8. https://doi.org/10.1200/JCO.2009.23.9764.

66. Wells SA Jr, Robinson BG, Gagel RF, Dralle H, Fagin JA, Santoro M, Baudin E, Elisei R, Jarzab B, Vasselli JR, Read
J, Langmuir P, Ryan AJ, et al. Vandetanib in patients with locally advanced or metastatic medullary thyroid cancer: a randomized, double-blind phase III trial. J Clin Oncol. 2012; 30:134-41. https://doi.org/10.1200/JCO.2011.35.5040.

67. Rini BI, Schiller JH, Fruehauf JP, Cohen EE, Tarazi JC, Rosbrook B, Bair AH, Ricart AD, Olszanski AJ, Letrent KJ, Kim S, Rixe O. Diastolic blood pressure as a biomarker of axitinib efficacy in solid tumors. Clin Cancer Res. 2011; 17:3841-9. https://doi.org/10.1158/1078-0432. CCR-10-2806.

68. Grothey A, Van Cutsem E, Sobrero A, Siena S, Falcone A, Ychou M, Humblet Y, Bouche O, Mineur L, Barone C, Adenis A, Tabernero J, Yoshino T, et al. Regorafenib monotherapy for previously treated metastatic colorectal cancer (CORRECT): an international, multicentre, randomised, placebo-controlled, phase 3 trial. Lancet. 2013; 381:303-12. https://doi.org/10.1016/ S0140-6736(12)61900-X.

69. Smith DC, Smith MR, Sweeney C, Elfiky AA, Logothetis C, Corn PG, Vogelzang NJ, Small EJ, Harzstark AL, Gordon MS, Vaishampayan UN, Haas NB, Spira AI, et al. Cabozantinib in patients with advanced prostate cancer: results of a phase II randomized discontinuation trial. J Clin Oncol. 2013; 31:412-9. https://doi.org/10.1200/ JCO.2012.45.0494.

70. Choueiri TK, Escudier B, Powles T, Tannir NM, Mainwaring PN, Rini BI, Hammers HJ, Donskov F, Roth BJ, Peltola K, Lee JL, Heng DYC, Schmidinger M, et al. Cabozantinib versus everolimus in advanced renal cell carcinoma (METEOR): final results from a randomised, open-label, phase 3 trial. Lancet Oncol. 2016; 17:917-27. https://doi.org/10.1016/S1470-2045(16)30107-3.

71. Usui J, Glezerman IG, Salvatore SP, Chandran CB, Flombaum CD, Seshan SV. Clinicopathological spectrum of kidney diseases in cancer patients treated with vascular endothelial growth factor inhibitors: a report of 5 cases and review of literature. Hum Pathol. 2014; 45:1918-27. https:// doi.org/10.1016/j.humpath.2014.05.015.

72. Stylianou K, Lioudaki E, Papadimitraki E, Kokologiannakis G, Kroustalakis N, Liotsi C, Giannakakis K, Georgoulias V, Daphnis E. Crescentic glomerulonephritis associated with vascular endothelial growth factor (VEGF) inhibitor and bisphosphonate administration. Nephrol Dial Transplant. 2011; 26:1742-5. https://doi.org/10.1093/ndt/gfr093.

73. Rolleman EJ, Weening J, Betjes MG. Acute nephritic syndrome after anti-VEGF therapy for renal cell carcinoma. Nephrol Dial Transplant. 2009; 24:2002-3. https://doi. org/10.1093/ndt/gfp140.

74. Costero O, Picazo ML, Zamora P, Romero S, Martinez-Ara J, Selgas R. Inhibition of tyrosine kinases by sunitinib associated with focal segmental glomerulosclerosis lesion in addition to thrombotic microangiopathy. Nephrol Dial Transplant. 2010; 25:1001-3. https://doi.org/10.1093/ndt/gfp666.

75. Chen YS, Chen CL, Wang JS. Nephrotic Syndrome and Acute Renal Failure Apparently Induced by 
Sunitinib. Case Rep Oncol. 2009; 2:172-6. https://doi. org/10.1159/000241551.

76. Winn SK, Ellis S, Savage P, Sampson S, Marsh JE. Biopsyproven acute interstitial nephritis associated with the tyrosine kinase inhibitor sunitinib: a class effect? Nephrol Dial Transplant. 2009; 24:673-5. https://doi.org/10.1093/ ndt/gfn625.

77. Miyake M, Kuwada M, Hori S, Morizawa Y, Tatsumi Y, Anai S, Hosokawa Y, Hayashi Y, Tomioka A, Otani T, Otsuka K, Nakagawa Y, Nakai Y, et al. The best objective response of target lesions and the incidence of treatmentrelated hypertension are associated with the survival of patients with metastatic renal cell carcinoma treated with sunitinib: a Japanese retrospective study. BMC Res Notes. 2016; 9:79. https://doi.org/10.1186/s13104-016-1895-8.

78. Bono P, Elfving H, Utriainen T, Osterlund P, Saarto T, Alanko T, Joensuu H. Hypertension and clinical benefit of bevacizumab in the treatment of advanced renal cell carcinoma. Ann Oncol. 2009; 20:393-4. https://doi. org/10.1093/annonc/mdn729.

79. Rini BI, Schiller JH, Fruehauf JP, Cohen EE, Tarazi JC, Rosbrook B, Ricart AD, Olszanski AJ, Kim S, Spano J. Association of diastolic blood pressure $(\mathrm{dBP}) \geq 90 \mathrm{mmHg}$ with overall survival (OS) in patients treated with axitinib (AG- 013736). Journal of Clinical Oncology. 2008; 26:3543. https://doi.org/10.1200/jco.2008.26.15_suppl.3543.

80. Sire M, Wallerand H, Kilkoski F, Grenier N, Ferriere JM, Ravaud A. [Anti-angiogenic treatment in the management of metastatic renal cell carcinoma]. [Article in French]. Bull Cancer. 2008; 95:813-20. https://doi.org/10.1684/ bdc.2008.0705.

81. Bondarenko IM, Ingrosso A, Bycott P, Kim S, Cebotaru CL. Phase II study of axitinib with doublet chemotherapy in patients with advanced squamous non-small-cell lung cancer. BMC Cancer. 2015; 15:339. https://doi.org/10.1186/ s12885-015-1350-6.

82. Sun Y, Niu W, Du F, Du C, Li S, Wang J, Li L, Wang F, Hao Y, Li C, Chi Y. Safety, pharmacokinetics, and antitumor properties of anlotinib, an oral multi-target tyrosine kinase inhibitor, in patients with advanced refractory solid tumors. J Hematol Oncol. 2016; 9:105. https://doi.org/10.1186/ s13045-016-0332-8.

83. Xu JM, Wang Y, Chen YL, Jia R, Li J, Gong JF, Li J, Qi C, Hua Y, Tan CR, Wang J, Li K, Sai Y, et al. Sulfatinib, a novel kinase inhibitor, in patients with advanced solid tumors: results from a phase I study. Oncotarget. 2017; 8:42076-86. https://doi.org/10.18632/oncotarget.14942.

84. Mittal K, Koon H, Elson P, Triozzi P, Dowlati A, Chen H, Borden EC, Rini BI. Dual VEGF/VEGFR inhibition in advanced solid malignancies: clinical effects and pharmacodynamic biomarkers. Cancer Biol Ther. 2014; 15:975-81. https://doi.org/10.4161/cbt.29187.

85. Algazi AP, Cha E, Ortiz-Urda SM, McCalmont T, Bastian BC, Hwang J, Pampaloni MH, Behr S, Chong K, Cortez B, Quiroz A, Coakley F, Liu S, et al. The combination of axitinib followed by paclitaxel/carboplatin yields extended survival in advanced BRAF wild-type melanoma: results of a clinical/ correlative prospective phase II clinical trial. Br J Cancer. 2015; 112:1326-31. https://doi.org/10.1038/bjc.2014.541.

86. Tomita Y, Fukasawa S, Oya M, Uemura H, Shinohara N, Habuchi T, Rini BI, Chen Y, Bair AH, Ozono S, Naito S, Akaza H. Key predictive factors for efficacy of axitinib in first-line metastatic renal cell carcinoma: subgroup analysis in Japanese patien ts from a randomized, double-blind phase II study. Jpn J Clin Oncol. 2016 Aug 29. https://doi. org/10.1093/jjco/hyw103. [Epub ahead of print].

87. Rini BI, Quinn DI, Baum M, Wood LS, Tarazi J, Rosbrook B, Arruda LS, Cisar L, Roberts WG, Kim S, Motzer RJ. Hypertension among patients with renal cell carcinoma receiving axitinib or sorafenib: analysis from the randomized phase III AXIS trial. Target Oncol. 2015; 10:45-53. https://doi.org/10.1007/s11523-014-0307-z.

88. Fuchs CS, Tomasek J, Yong CJ, Dumitru F, Passalacqua R, Goswami C, Safran H, Dos Santos LV, Aprile G, Ferry DR, Melichar B, Tehfe M, Topuzov E, et al. Ramucirumab monotherapy for previously treated advanced gastric or gastro-oesophageal junction adenocarcinoma (REGARD): an international, randomised, multicentre, placebocontrolled, phase 3 trial. Lancet. 2014; 383:31-9. https:// doi.org/10.1016/S0140-6736(13)61719-5.

89. Schlumberger M, Tahara M, Wirth LJ, Robinson B, Brose MS, Elisei R, Habra MA, Newbold K, Shah MH, Hoff AO, Gianoukakis AG, Kiyota N, Taylor MH, et al. Lenvatinib versus placebo in radioiodine-refractory thyroid cancer. $\mathrm{N}$ Engl J Med. 2015; 372:621-30. https://doi.org/10.1056/ NEJMoa1406470.

90. An MM, Zou Z, Shen H, Liu P, Chen ML, Cao YB, Jiang YY. Incidence and risk of significantly raised blood pressure in cancer patients treated with bevacizumab: an updated meta-analysis. Eur J Clin Pharmacol. 2010; 66:813-21. https://doi.org/10.1007/s00228-010-0815-4.

91. Zhu X, Stergiopoulos K, Wu S. Risk of hypertension and renal dysfunction with an angiogenesis inhibitor sunitinib: systematic review and meta-analysis. Acta Oncol. 2009; 48:9-17. https://doi.org/10.1080/02841860802314720.

92. Wu S, Chen JJ, Kudelka A, Lu J, Zhu X. Incidence and risk of hypertension with sorafenib in patients with cancer: a systematic review and meta-analysis. Lancet Oncol. 2008; 9:117-23. https://doi.org/10.1016/S1470-2045(08)70003-2.

93. Abdel-Rahman O, Fouad M. Risk of cardiovascular toxicities in patients with solid tumors treated with sorafenib: an updated systematic review and meta-analysis. Future Oncol. 2014; 10:1981-92. https://doi.org/10.2217/fon.14.42.

94. Abdel-Rahman O, Fouad M. Risk of cardiovascular toxicities in patients with solid tumors treated with sunitinib, axitinib, cediranib or regorafenib: an updated systematic review and comparative meta-analysis. Crit Rev Oncol Hematol. 2014; 92:194-207. https://doi. org/10.1016/j.critrevonc.2014.06.003. 
95. Qi WX, Lin F, Sun YJ, Tang LN, He AN, Yao Y, Shen Z. Incidence and risk of hypertension with pazopanib in patients with cancer: a meta-analysis. Cancer Chemother Pharmacol. 2013; 71:431-9. https://doi.org/10.1007/ s00280-012-2025-5.

96. Funakoshi T, Latif A, Galsky MD. Risk of hypertension in cancer patients treated with sorafenib: an updated systematic review and meta-analysis. J Hum Hypertens. 2013; 27:601-11. https://doi.org/10.1038/jhh.2013.30.

97. Escalante CP, Lu M, Marten CA. Update of Targeted Therapy-Induced Hypertension: Basics for Non-Oncology Providers. Curr Hypertens Rev. 2016; 12:112-20.

98. Kroschinsky F, Stölzel F, von Bonin S, Beutel G, Kochanek M, Kiehl M, Schellongowski P; Intensive Care in Hematological and Oncological Patients (iCHOP) Collaborative Group. New drugs, new toxicities: severe side effects of modern targeted and immunotherapy of cancer and their management. Crit Care. 2017; 21:89. https://doi. org/10.1186/s13054-017-1678-1.

99. Semeniuk-Wojtas A, Lubas A, Stec R, Szczylik C, Niemczyk S. Influence of Tyrosine Kinase Inhibitors on Hypertension and Nephrotoxicity in Metastatic Renal Cell Cancer Patients. Int J Mol Sci. 2016; 17. https://doi. org/10.3390/ijms17122073.

100. Hamnvik OP, Choueiri TK, Turchin A, McKay RR, Goyal L, Davis M, Kaymakcalan MD, Williams JS. Clinical risk factors for the development of hypertension in patients treated with inhibitors of the VEGF signaling pathway. Cancer. 2015; 121:311-9. https://doi.org/10.1002/ cncr.28972.

101. Maitland ML, Kasza KE, Karrison T, Moshier K, Sit L, Black HR, Undevia SD, Stadler WM, Elliott WJ, Ratain MJ. Ambulatory monitoring detects sorafenib-induced blood pressure elevations on the first day of treatment. Clin Cancer Res. 2009; 15:6250-7. https://doi.org/10.1158/10780432.CCR-09-0058.

102. Azizi M, Chedid A, Oudard S. Home blood-pressure monitoring in patients receiving sunitinib. N Engl J Med. 2008; 358:95-7. https://doi.org/10.1056/NEJMc072330.

103. Schneider BP, Li L, Shen F, Miller KD, Radovich M, O'Neill A, Gray RJ, Lane D, Flockhart DA, Jiang G, Wang Z, Lai D, Koller D, et al. Genetic variant predicts bevacizumab-induced hypertension in ECOG-5103 and ECOG-2100. Br J Cancer. 2014; 111:1241-8. https://doi. org/10.1038/bjc.2014.430.

104. Sibertin-Blanc C, Mancini J, Fabre A, Lagarde A, Del Grande J, Levy N, Seitz JF, Olschwang S, Dahan L. Vascular Endothelial Growth Factor A c. ${ }^{* 237 C}>\mathrm{T}$ polymorphism is associated with bevacizumab efficacy and related hypertension in metastatic colorectal cancer. Dig Liver Dis. 2015; 47:331-7. https://doi.org/10.1016/j. dld.2014.12.013.

105. Maitland ML, Bakris GL, Black HR, Chen HX, Durand JB, Elliott WJ, Ivy SP, Leier CV, Lindenfeld J, Liu G, Remick SC, Steingart R, Tang WH, et al. Initial assessment, surveillance, and management of blood pressure in patients receiving vascular endothelial growth factor signaling pathway inhibitors. J Natl Cancer Inst. 2010; 102:596-604. https://doi.org/10.1093/jnci/djq091.

106. Dahlberg SE, Sandler AB, Brahmer JR, Schiller JH, Johnson DH. Clinical course of advanced non-small-cell lung cancer patients experiencing hypertension during treatment with bevacizumab in combination with carboplatin and paclitaxel on ECOG 4599. J Clin Oncol. 2010; 28:949-54. https://doi. org/10.1200/JCO.2009.25.4482.

107. Schneider BP, Wang M, Radovich M, Sledge GW, Badve S, Thor A, Flockhart DA, Hancock B, Davidson N, Gralow J, Dickler M, Perez EA, Cobleigh M, et al. Association of vascular endothelial growth factor and vascular endothelial growth factor receptor-2 genetic polymorphisms with outcome in a trial of paclitaxel compared with paclitaxel plus bevacizumab in advanced breast cancer: ECOG 2100. J Clin Oncol. 2008; 26:4672-8. https://doi.org/10.1200/ JCO.2008.16.1612.

108. Ryanne Wu R, Lindenberg PA, Slack R, Noone AM, Marshall JL, He AR. Evaluation of hypertension as a marker of bevacizumab efficacy. J Gastrointest Cancer. 2009; 40:101-8. https://doi.org/10.1007/s12029-009-9104-9.

109. Scartozzi M, Galizia E, Chiorrini S, Giampieri R, Berardi R, Pierantoni C, Cascinu S. Arterial hypertension correlates with clinical outcome in colorectal cancer patients treated with first-line bevacizumab. Ann Oncol. 2009; 20:227-30. https://doi.org/10.1093/annonc/mdn637.

110. Goodwin R, Ding K, Seymour L, LeMaitre A, Arnold A, Shepherd FA, Dediu M, Ciuleanu T, Fenton D, Zukin M, Walde D, Laberge F, Vincent M, et al. Treatment-emergent hypertension and outcomes in patients with advanced non-small-cell lung cancer receiving chemotherapy with or without the vascular endothelial growth factor receptor inhibitor cediranib: NCIC Clinical Trials Group Study BR24. Ann Oncol. 2010; 21:2220-6. https://doi. org/10.1093/annonc/mdq221.

111. Rini BI, Cohen DP, Lu DR, Chen I, Hariharan S, Gore ME, Figlin RA, Baum MS, Motzer RJ. Hypertension as a biomarker of efficacy in patients with metastatic renal cell carcinoma treated with sunitinib. J Natl Cancer Inst. 2011; 103:763-73. https://doi.org/10.1093/jnci/djr128.

112. Estfan B, Byrne M, Kim R. Sorafenib in advanced hepatocellular carcinoma: hypertension as a potential surrogate marker for efficacy. Am J Clin Oncol. 2013; 36:319-24. https://doi.org/10.1097/COC.0b013e3182468039.

113. Donskov F, Michaelson MD, Puzanov I, Davis MP, Bjarnason GA, Motzer RJ, Goldstein D, Lin X, Cohen DP, Wiltshire R, Rini BI. Sunitinib-associated hypertension and neutropenia as efficacy biomarkers in metastatic renal cell carcinoma patients. Br J Cancer. 2015; 113:1571-80. https://doi.org/10.1038/bjc.2015.368.

114. Wick A, Schafer N, Dorner N, Schemmer D, Platten M, Bendszus M, Wick W. Arterial hypertension and bevacizumab treatment in glioblastoma: no correlation with 
clinical outcome. J Neurooncol. 2010; 97:157-8. https://doi. org/10.1007/s11060-009-0003-5.

115. Hurwitz HI, Douglas PS, Middleton JP, Sledge GW, Johnson DH, Reardon DA, Chen D, Rosen O. Analysis of early hypertension and clinical outcome with bevacizumab: results from seven phase III studies. Oncologist. 2013; 18:273-80. https://doi.org/10.1634/ theoncologist.2012-0339.

116. Houk BE, Bello CL, Poland B, Rosen LS, Demetri GD, Motzer RJ. Relationship between exposure to sunitinib and efficacy and tolerability endpoints in patients with cancer: results of a pharmacokinetic/pharmacodynamic metaanalysis. Cancer Chemother Pharmacol. 2010; 66:357-71. https://doi.org/10.1007/s00280-009-1170-y.

117. De Stefano A, Carlomagno C, Pepe S, Bianco R, De Placido S. Bevacizumab-related arterial hypertension as a predictive marker in metastatic colorectal cancer patients. Cancer Chemother Pharmacol. 2011; 68:1207-13. https:// doi.org/10.1007/s00280-011-1604-1.

118. Rixe O, Billemont B, Izzedine H. Hypertension as a predictive factor of Sunitinib activity. Ann Oncol. 2007; 18:1117. https://doi.org/10.1093/annonc/mdm184.

119. Feldman DR, Baum MS, Ginsberg MS, Hassoun H, Flombaum CD, Velasco S, Fischer P, Ronnen E, Ishill N, Patil S, Motzer RJ. Phase I trial of bevacizumab plus escalated doses of sunitinib in patients with metastatic renal cell carcinoma. J Clin Oncol. 2009; 27:1432-9. https://doi. org/10.1200/JCO.2008.19.0108.

120. Azad NS, Posadas EM, Kwitkowski VE, Steinberg SM, Jain L, Annunziata CM, Minasian L, Sarosy G, Kotz HL, Premkumar A, Cao L, McNally D, Chow C, et al. Combination targeted therapy with sorafenib and bevacizumab results in enhanced toxicity and antitumor activity. J Clin Oncol. 2008; 26:3709-14. https://doi. org/10.1200/JCO.2007.10.8332.

121. Bress AP, Bellows BK, King JB, Hess R, Beddhu S, Zhang Z, Berlowitz DR, Conroy MB, Fine L, Oparil S, Morisky DE, Kazis LE, Ruiz-Negron N, et al. Cost-Effectiveness of Intensive versus Standard Blood-Pressure Control. N Engl J Med. 2017; 377:745-55. https://doi.org/10.1056/ NEJMsa1616035.

122. James PA, Oparil S, Carter BL, Cushman WC, DennisonHimmelfarb C, Handler J, Lackland DT, LeFevre ML, MacKenzie TD, Ogedegbe O, Smith SC Jr, Svetkey LP, Taler SJ, et al. 2014 evidence-based guideline for the management of high blood pressure in adults: report from the panel members appointed to the Eighth Joint National Committee (JNC 8). JAMA. 2014; 311:507-20. https://doi. org/10.1001/jama.2013.284427.

123. Jessup M, Abraham WT, Casey DE, Feldman AM, Francis GS, Ganiats TG, Konstam MA, Mancini DM, Rahko PS, Silver MA, Stevenson LW, Yancy CW. 2009 focused update: ACCF/AHA Guidelines for the Diagnosis and Management of Heart Failure in Adults: a report of the American College of Cardiology Foundation/American Heart Association Task
Force on Practice Guidelines: developed in collaboration with the International Society for Heart and Lung Transplantation. Circulation. 2009; 119:1977-2016. https:// doi.org/10.1161/CIRCULATIONAHA.109.192064.

124. Mancia G, Fagard R, Narkiewicz K, Redon J, Zanchetti A, Bohm M, Christiaens T, Cifkova R, De Backer G, Dominiczak A, Galderisi M, Grobbee DE, Jaarsma T, et al. $2013 \mathrm{ESH} / \mathrm{ESC}$ Guidelines for the management of arterial hypertension: the Task Force for the management of arterial hypertension of the European Society of Hypertension (ESH) and of the European Society of Cardiology (ESC). J Hypertens. 2013; 31:1281-357. https://doi.org/10.1097/01. hjh.0000431740.32696.cc.

125. Piccirillo JF, Tierney RM, Costas I, Grove L, Spitznagel EL Jr. Prognostic importance of comorbidity in a hospitalbased cancer registry. JAMA. 2004; 291:2441-7. https:// doi.org/10.1001/jama.291.20.2441.

126. Zamorano JL, Lancellotti P, Rodriguez Munoz D, Aboyans V, Asteggiano R, Galderisi M, Habib G, Lenihan DJ, Lip GY, Lyon AR, Lopez Fernandez T, Mohty D, Piepoli MF, et al. 2016 ESC Position Paper on cancer treatments and cardiovascular toxicity developed under the auspices of the ESC Committee for Practice Guidelines: The Task Force for cancer treatments and cardiovascular toxicity of the European Society of Cardiology (ESC). Eur Heart J. 2016; 37:2768-801. https://doi.org/10.1093/eurheartj/ehw211.

127. Yancy CW, Jessup M, Bozkurt B, Butler J, Casey DE Jr, Drazner MH, Fonarow GC, Geraci SA, Horwich T, Januzzi JL, Johnson MR, Kasper EK, Levy WC, et al. 2013 ACCF/ AHA guideline for the management of heart failure: a report of the American College of Cardiology Foundation/ American Heart Association Task Force on Practice Guidelines. J Am Coll Cardiol. 2013; 62:e147-239. https:// doi.org/10.1016/j.jacc.2013.05.019.

128. Small HY, Montezano AC, Rios FJ, Savoia C, Touyz RM. Hypertension due to antiangiogenic cancer therapy with vascular endothelial growth factor inhibitors: understanding and managing a new syndrome. Can J Cardiol. 2014; 30:534-43. https://doi.org/10.1016/j.cjca.2014.02.011.

129. Li W, Croce K, Steensma DP, McDermott DF, BenYehuda O, Moslehi J. Vascular and Metabolic Implications of Novel Targeted Cancer Therapies: Focus on Kinase Inhibitors. J Am Coll Cardiol. 2015; 66:1160-78. https:// doi.org/10.1016/j.jacc.2015.07.025.

130. Ranpura V, Pulipati B, Chu D, Zhu X, Wu S. Increased risk of high-grade hypertension with bevacizumab in cancer patients: a meta-analysis. Am J Hypertens. 2010; 23:460-8. https://doi.org/10.1038/ajh.2010.25.

131. Joensuu H. Cardiac toxicity of sunitinib. Lancet. 2007; 370:1978-80. https://doi.org/10.1016/S0140-6736(07)61840-6.

132. Carver JR, Schuster SJ, Glick JH. Doxorubicin cardiotoxicity in the elderly: old drugs and new opportunities. J Clin Oncol. 2008; 26:3122-4. https://doi. org/10.1200/JCO.2008.16.5274. 
133. Akl EA, Kahale LA, Hakoum MB, Matar CF, Sperati F, Barba M, Yosuico VED, Terrenato I, Synnot A, Schunemann H. Parenteral anticoagulation in ambulatory patients with cancer. Cochrane Database Syst Rev. 2017; 9:CD006652. https://doi.org/10.1002/14651858.CD006652. pub5.

134. Uppuluri EM, Burke KR, Haaf CM, Shapiro NL. Assessment of venous thromboembolism treatment in patients with cancer on low molecular weight heparin, warfarin, and the direct oral anticoagulants. J Oncol Pharm Pract. 2017; 1078155217730129. https://doi. org/10.1177/1078155217730129.

135. Pritchard ER, Murillo JR Jr, Putney D, Hobaugh EC. Singlecenter, retrospective evaluation of safety and efficacy of direct oral anticoagulants versus low-molecular-weight heparin and vitamin $\mathrm{K}$ antagonist in patients with cancer. J Oncol Pharm Pract. 2017; 1078155217726158. https://doi. org/10.1177/1078155217726158.

136. Alzghari SK, Seago SE, Garza JE, Hashimie YF, Baty KA, Evans MF, Shaver C, Herrington JD. Retrospective comparison of low molecular weight heparin vs. warfarin vs. oral Xa inhibitors for the prevention of recurrent venous thromboembolism in oncology patients: The Re-CLOT study. J Oncol Pharm Pract. 2017; 1078155217718382. https://doi.org/10.1177/1078155217718382.

137. Xiang E, Ahuja T, Raco V, Cirrone F, Green D, Papadopoulos J. Anticoagulation prescribing patterns in patients with cancer. J Thromb Thrombolysis. 2017; 45: 89-98. https://doi.org/10.1007/s11239-017-1558-1.

138. Melloni C, Dunning A, Granger CB, Thomas L, Khouri MG, Garcia DA, Hylek EM, Hanna M, Wallentin L, Gersh BJ, Douglas PS, Alexander JH, Lopes RD. Efficacy and Safety of Apixaban Versus Warfarin in Patients with Atrial Fibrillation and a History of Cancer: Insights from the ARISTOTLE Trial. Am J Med. 2017; 130:1440-8.e1. https://doi.org/10.1016/j.amjmed.2017.06.026.

139. Maraveyas A, Muazzam I, Noble S, Bozas G. Advances in managing and preventing thromboembolic disease in cancer patients. Curr Opin Support Palliat Care. 2017; 11:347-54. https://doi.org/10.1097/SPC.0000000000000309.

140. Haaland GS, Falk RS, Straume O, Lorens JB. Association of Warfarin Use With Lower Overall Cancer Incidence Among Patients Older Than 50 Years. JAMA Intern Med. 2017; 177:1774-80. https://doi.org/10.1001/ jamainternmed.2017.5512.

141. Mlodawska E, Tomaszuk-Kazberuk A, Lopatowska P, Musial WJ, Malyszko J. Management of patients with atrial fibrillation and chronic kidney disease in light of the latest guidelines. Pol Arch Med Wewn. 2016; 126:353-62. https:// doi.org/10.20452/pamw.3431.

142. Richman IB, Owens DK. Aspirin for Primary Prevention. Med Clin North Am. 2017; 101:713-24. https://doi. org/10.1016/j.mcna.2017.03.004.
143. Whitlock EP, Williams SB, Burda BU, Feightner A, Beil T. (2015). Aspirin Use in Adults: Cancer, All-Cause Mortality, and Harms: A Systematic Evidence Review for the US Preventive Services Task Force. (Rockville (MD).

144. Matsuo K, Cahoon SS, Yoshihara K, Shida M, Kakuda M, Adachi S, Moeini A, Machida H, Garcia-Sayre J, Ueda Y, Enomoto T, Mikami M, Roman LD, et al. Association of Low-Dose Aspirin and Survival of Women With Endometrial Cancer. Obstet Gynecol. 2016; 128:127-37. https://doi.org/10.1097/AOG.0000000000001491.

145. Dowling RJ, Zakikhani M, Fantus IG, Pollak M, Sonenberg N. Metformin inhibits mammalian target of rapamycin-dependent translation initiation in breast cancer cells. Cancer Res. 2007; 67:10804-12. https://doi. org/10.1158/0008-5472.CAN-07-2310.

146. Gotlieb WH, Saumet J, Beauchamp MC, Gu J, Lau S, Pollak MN, Bruchim I. In vitro metformin anti-neoplastic activity in epithelial ovarian cancer. Gynecol Oncol. 2008; 110:246-50. https://doi.org/10.1016/j.ygyno.2008.04.008.

147. Kalender A, Selvaraj A, Kim SY, Gulati P, Brule S, Viollet B, Kemp BE, Bardeesy N, Dennis P, Schlager JJ, Marette A, Kozma SC, Thomas G. Metformin, independent of AMPK, inhibits mTORC1 in a rag GTPase-dependent manner. Cell Metab. 2010; 11:390-401. https://doi.org/10.1016/j. cmet.2010.03.014.

148. Evans JM, Donnelly LA, Emslie-Smith AM, Alessi DR, Morris AD. Metformin and reduced risk of cancer in diabetic patients. BMJ. 2005; 330:1304-5. https://doi. org/10.1136/bmj.38415.708634.F7.

149. Decensi A, Puntoni M, Goodwin P, Cazzaniga M, Gennari A, Bonanni B, Gandini S. Metformin and cancer risk in diabetic patients: a systematic review and meta-analysis. Cancer Prev Res (Phila). 2010; 3:1451-61. https://doi. org/10.1158/1940-6207.CAPR-10-0157.

150. Libby G, Donnelly LA, Donnan PT, Alessi DR, Morris AD, Evans JM. New users of metformin are at low risk of incident cancer: a cohort study among people with type 2 diabetes. Diabetes Care. 2009; 32:1620-5. https://doi. org/10.2337/dc08-2175.

151. Landman GW, Kleefstra N, van Hateren KJ, Groenier KH, Gans RO, Bilo HJ. Metformin associated with lower cancer mortality in type 2 diabetes: ZODIAC-16. Diabetes Care. 2010; 33:322-6. https://doi.org/10.2337/dc09-1380.

152. Chen YC, Kok VC, Chien CH, Horng JT, Tsai JJ. Cancer risk in patients aged 30 years and above with type 2 diabetes receiving antidiabetic monotherapy: a cohort study using metformin as the comparator. Ther Clin Risk Manag. 2015; 11:1315-23. https://doi.org/10.2147/TCRM.S91513.

153. Hanprasertpong J, Jiamset I, Geater A, Peerawong T, Hemman W, Kornsilp S. The Effect of Metformin on Oncological Outcomes in Patients With Cervical Cancer With Type 2 Diabetes Mellitus. Int J Gynecol Cancer. 2017; 27:131-7. https://doi.org/10.1097/IGC.0000000000000855. 
154. Yen YC, Lin C, Lin SW, Lin YS, Weng SF. Effect of metformin on the incidence of head and neck cancer in diabetics. Head Neck. 2015; 37:1268-73. https://doi. org/10.1002/hed.23743.

155. Becker C, Jick SS, Meier CR, Bodmer M. Metformin and the risk of renal cell carcinoma: a case-control analysis. Eur J Cancer Prev. 2017; 26:257-62. https://doi.org/10.1097/ CEJ.0000000000000246.

156. Braithwaite D, Tammemagi CM, Moore DH, Ozanne EM, Hiatt RA, Belkora J, West DW, Satariano WA, Liebman M, Esserman L. Hypertension is an independent predictor of survival disparity between African-American and white breast cancer patients. Int J Cancer. 2009; 124:1213-9. https://doi.org/10.1002/ijc. 24054.
157. Chang HM, Okwuosa TM, Scarabelli T, Moudgil R, Yeh ETH. Cardiovascular Complications of Cancer Therapy: Best Practices in Diagnosis, Prevention, and Management: Part 2. J Am Coll Cardiol. 2017; 70:2552-65. https://doi. org/10.1016/j.jacc.2017.09.1095.

158. Jovenaux L, Cautela J, Resseguier N, Pibarot M, Taouqi M, Orabona M, Pinto J, Peyrol M, Barraud J, Laine M, Bonello L, Paganelli F, Barlesi F, et al. Practices in management of cancer treatment-related cardiovascular toxicity: A cardiooncology survey. Int J Cardiol. 2017; 241:387-92. https:// doi.org/10.1016/j.ijcard.2017.02.154. 